\title{
Desain Alat Sterilisasi Covid-19 dengan Teknologi Sinar UV yang Ramah untuk Anak-anak Usia 2-6 Tahun
}

\author{
Yosef Richo, Martinus Sony, dan Hafidz Sirojul \\ Desain Produk, Fakultas Desain dan Industri Kreatif, \\ Universitas Dinamika, Surabaya, Indonesia \\ e-mail: yosef@dinamika.ac.id
}

\begin{abstract}
Abstrak-Pencegahan sejak dini terkait Covid-19 perlu dilakukan masyarakat. Meskipun Vaksin sudah dilaksaaannnakan oleh pemerintah, namun langkah pencegahan Virus Covid 19 tetap wajib dilakukan. Apalagi untuk anak kecil (usia 2-6 tahun) yang bersekolah pada jenjang TK/Playgorup tentunya harus lebih dicermati, karena anak-anak memiliki pemahaman yang tidak sekompleks orang dewasa. Sekolah umumnya sudah menggunakan produk pendukung untuk program sterilisasi Covid-19 bagi mudridnya. Beberapa penelitian sebelumnya membuktikan Lampu LED (ultra Violet) dan hand sanizer mampu dengan cepat membunuh virus yang menempel pada benda-benda, untuk itu peneliti mencoba membuat suatu desain lemari sederhana untuk meletakkan barang bawaan dari luar ruangan yang didalamnya mampu membasmi virus Covid dengan bantuan Lampu $L E D$ dan Hand sanitizer. Selanjutnya ditentukan skala prioritas dengan menggunakan metode sampling. Tempat sampling pada beberapa lokasi Sekolah mengenai beberapa bentuk yang disukai anak. Hal ini diperlukan karena anak cenderung takut dengan produk baru yang asing terutama yang bersifat medis. Setelah prioritas produk ditentukan, selajutnya peneliti melakukan proses new product development dengan metode $Q F D$ untuk menentukan final desain. Final desain yang sudah terbentuk selanjutnya dilakukan finishing dengan menggunakan program komputer untuk melihat hasil akhir dan siap diproduksi. Tujuan riset ini adalah memberikan menajemen perancangan pada sebuah desain produk sterilisiasi Covid-19 untuk sekolah tingkat dasa yang ramah bagi anak-anak.
\end{abstract}

Kata kunci: desain, sterilisasi Covid-19, anak-anak, vaksin, dan taman kanak-kanak.

Abstract - Early prevention related to Covid-19 needs to be done by the community. Even though the government has implemented a vaccine, it is still mandatory to take steps to prevent the Covid19 virus. Especially for small children (aged 2-6 years) who attend kindergarten/Playgroup level, of course, it must be more closely observed, because children have an understanding that is not as complex as adults. Schools have generally used supporting products for the Covid-19 sterilization program for their students. Several previous studies have proven that LED (ultra Violet) lights and hand sanitizers are able to quickly kill viruses that stick to objects, for that researchers tried to make a simple wardrobe design to put luggage from outside the room in which it was able to eradicate the Covid virus with the help of lights. LED and hand sanitizer. Furthermore, the priority scale is determined using the sampling method. Sampling places at several school locations regarding several forms that children like. This is necessary because children tend to be afraid of new, unfamiliar products, especially medical ones. After the priority of the product is determined, the researcher then conducts a new product development process using the QFD method to determine the final design. The final design that has been formed is then finished using a computer program to see the final result and is ready to be produced. The purpose of this research is to provide design management for a Covid-19 sterilization product design for elementary-level schools that are friendly for children.

Keywords: design, Covid-19 sterilization, children, vaccine, and kindergarten.

\section{PENDAHULUAN}

Virus Sars-19 atau lebih dikenal dengan virus Covid-19 telah melanda dan menyebar ke seluruh penjuru dunia, hingga sampai artikel ini dibuat virus Covid masih menjadi pandemi. Virus Covid ini ketahui pertama kali di kota Wuhan China pada awal tahun 2020 dan menyebar sangat cepat dan sangat sulit dihentikan.

Seperti diketahui bahwa virus ini menyebar dengan cara melalui perantara interaksi manusia dan menyebar diudara kemudian masuk kedalam hidung atau mulut selanjutnya masuk ke paru-paru sehingga merusak jaringan paru-paru menimbulkan kesulitan pernapasan hingga mengakibatkan kematian karena korban kekurangan oksigen. Menurut data dari woldometer.com hingga bulan juli 2021, dalam setahun lebih korban terinfeksi Covid mencapai 130 juta lebih dan kematian hingga 4 juta orang.

Covid Di Indonesia bisa cepat berakhir, jika pemerintah mau mengedukasi bahaya Covid serta memberikan bantuan program penanganan Covid [1]. Pemerintah sudah menggalakkan program $5 \mathrm{M}$ untuk mencegah penularan Covid yakni (memakai masker, mencuci tangan pakai sabun dan air mengalir, menjaga jarak, menjauhi kerumunan, serta membatasi mobilisasi dan interaksi). Juga dilakukan vaksinasi kepada masyarakat, namun vaksinasi membutuhkan waktu untuk dapat diterima seluruh masyarakat Indonesia yang berjumlah lebih dari 250 juta ini [2].

Namun demikian penaggulangan mediasi lainnya perlu dilakukan selain program-program tersebut diatas karena virus Covid selain menyebar lewat mediasi udara ternyata juga bisa menempel dan bertahan pada barang-barang yang dipakai seseorang hingga selama beberapa hari. Hasil penelitian menyebutkan bahwa virus Covid bisa bertahan pada material plastik hingga 5 hari. Hal ini perlu dicermati secara mendalam karena resiko tertular Covid yang menempel pada benda cukup besar mengingat ketika seseorang berada didalam rumah dan melepas masker serta selesai mencuci tangan hingga kering, seseorang masih berpeluang menghirup Covid yang menempel pada benda. Tabel 1 menunjukkan benda-benda dengan material tertentu 
yang berpeluang tertempel virus berikut lama menempelnya [3].

Tabel 1. Lama virus Covid-19 menempel pada benda.

\begin{tabular}{r|l|l}
\hline \hline No & Jenis benda & \multicolumn{1}{|c}{ Lama Virus dapat Menempel } \\
\hline \hline 1 & Baja & pada $20^{\circ} \mathrm{C} 48$ jam/2 hari \\
\hline 2 & Aluminium & pada suhu $20^{\circ} \mathrm{C}, 2-8$ jam \\
\hline 3 & Logam & suhu ruangan, 5 hari \\
\hline 4 & Kayu & suhu ruangan, 4 hari \\
\hline 5 & Kertas & suhu ruangan, 4-5 hari \\
\hline 6 & Plastik & suhu $22-25^{\circ} \mathrm{C}$, kurang lebih 5 hari \\
\hline 7 & Kain & pada suhu ruangan, 2 hari \\
\hline 8 & Kaca & pada suhu ruangan, 4 hari \\
\hline
\end{tabular}

Menjadi penting untuk dapat menentukan cara efektif penanggulangan virus agar dapat segera dihilangkan. Terdapat beberapa cara mematikan virus diudara ataupun yang menempel pada benda-benda yakni dengan semprotan air sabun atau disinfektan atau dengan menggunakan lampu LED ultra Violet. Sejumlah peneliti dari Tel Aviv University Israel, menemukan bahwa lampu LED dapat memancarkan sinar ultraviolet (UV). Lampu LED dengan sinar UV tersebut diklaim bisa membunuh virus Corona. Para peneliti tersebut mengklaim temuan itu merupakan studi pertama mengenai efisiensi desinfeksi virus Covid-19 dengan UV LED panjang gelombang atau frekuensi berbeda. Penelitian tersebut dipimpin Prof Hadas Mamane dari School of Mechanical Engineering, Tel Aviv University. Cara ini dapat mencegah penularan Corona di dalam ruangan Dalam penelitian, ditemukan bahwa dengan panjang gelombang 285 nanometer dalam waktu kurang satu menit dapat menghancurkan lebih dari 99,9 persen virus Corona [4].

Untuk mendapatkan panjang gelombang tersebut, cukup menggunakan bohlam LED $285 \mathrm{~nm}$ yang dapat disesuaikan untuk sistem robotik, AC, vakum, dan air. Bohlam LED yang dapat dipasang pada berbagai perabot itu membuat disinfeksi permukaan dan ruangan yang lebih besar. Prof Mamane berpendapat disinfeksi virus corona dengan UV LED lebih efektif dibandingkan dengan bahan kimia.

Dari tinjauan latar belakang dapat diketahui bahwa sinar ultraviolet dan semprotan disinfektan mempu menjadi sterilisasi virus Covid yang beterbangan diudara dan yang menempel dibenda, maka adalah peluang bagi desainer produk bagaimana memanfaatkan sebuah desain produk yang dapat memanfaatkan sinar ultra violet dan semprotan disifektan yang berguna bagi ruangan indoor untuk mencegah virus masuk kedalam ruangan.

\section{Kebutuhan sterilisasi pada Sekolah TK/Playgroup}

Setelah agenda vaksisnisasi yang dilakukan pemerintah Indoneisa selesai. Tetap saja masyarakat perlu melakukan pencegahan virus Covid dikarenakan virus masih dapat menginfeksi orang walaupun telah memperoleh vaksin. Produk sterilisasi Covid menjadi penting bagi sekolah tingkat dasar, terutama jika nanti murid sudah mulai masuk sekolah tatap muka kembali.

Meskipun produk sterilisasi dengan menggunakan lampu UV masih belum banyak digunakan di sekolah TK, namun potensi produk ini berpotensi tinggi dikarenakan murid TK membawa barang bawaan dari luar yang dicurigai membawa virus yang akan dibawa masuk kedalam area sekolah.

\section{Permasalahan}

Terdapat beberapa permasalahan didalam penerapan atau perancangan desain produk sterilisasi sinar $U V$ untuk penggunaan di sekolah dasar yaitu:

a. Secara umum produk sterilisasi UV yang sudah ada dipasaran berupa box yang dapat memuat atau dimasuki barang untuk disterilisasi didalam box. Bagaimana desain pada produk ini nantinya dapat sesuai dengan sekolah sehingga dapat menarik bagi anak-anak TK agar tidak nampak terlalu kaku atau nampak menakutkan bagi anak-anak.

b. Apakah produk sterilisasi UV ini dapat dikembangkan menjadi berbagai macam kriteria yang dapat diterapkan pada beberapa alternatif penempatan lingkungan TK/Playgroup.

c. Bagaimana prosedur produk steriliasi $U V$ ini dapat dipahami oleh anak TK/Playgroup dengan mudah dan tidak membahayakan penggunaannya.

Penelitian ini bertujuan utama untuk memperoleh desain alat strilisasi Covid-19 yang ramah bagi anak TK/playgroup.

\section{Batasan penelitian}

Penelitian ini terbatas pada pengembangan desain produk untuk sterilisasi Covid-19 dengan menggunakan sinar $U V$ dan selanjutnya pengguna adalah anak kecil berusia 2-6 tahun yang telah bersekolah pada tingkat playgroup dan TK (Taman kanak-kanak).

\section{METODE}

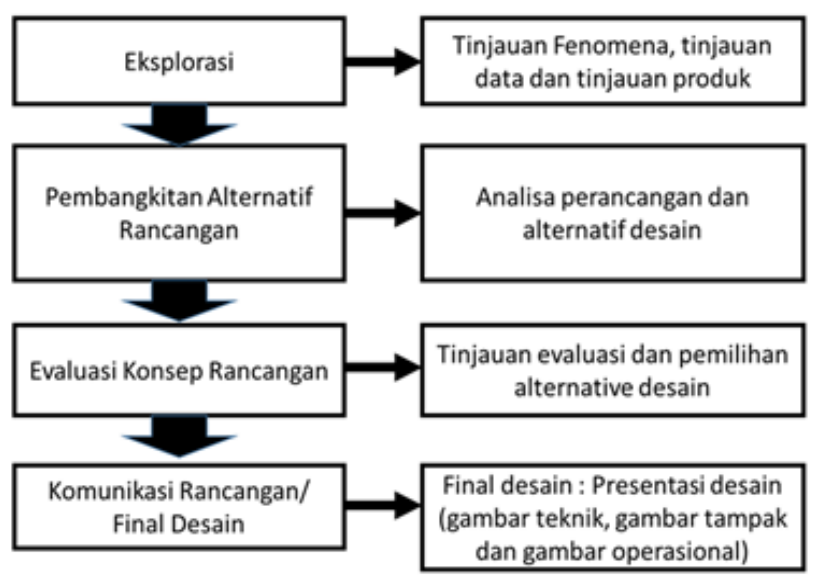

Gambar 1. Tahapan perancangan deskriptif.

Metode yang digunakan dalam artikel ini adalah deskriptif, dimana dalam hal ini peneliti mengkaji tentang fenomena dari Covid-19 dan perilaku yang dilakukan masyarakat pada masa tersebut [5].

Penelitian deskriptif ialah suatu penelitian yang berusaha menjawab permasalahan yang ada berdasarkan data-data (Gambar 1). Proses analisis dalam penelitian deskriptif yaitu, menyajikan, menganalisis, dan menginterpretasikan. Hal tersebut juga dilakukan dalam artikel ini yakni dengan melihat korelasi fenomena dengan data-data yang ada sebelumnya terkait Covid dengan penerapan pada kebutuhan 
produk sterilisasi UV. Setelah fenomena dan data didapatkan, maka peneliti dapat melanjutkan pada proses perancangan produk [6]. Model deskriptif ini berfokus pada solusi, heuristic (pengalaman atau fenomena sebelumnya, bersifat umum, dan rule of thumb) [7].

Langkah-langkah selanjutnya dilaksanakan sebagai berikut:

1. Eksplorasi mengumpulkan data terkait produk fenomena dan data terkait produk.

2. Mengkaji atribut-atribut untuk perancangan produk selanjutnya membuat beberapa alternatif pilihan kategori untuk masing-masing atribut.

3. Melakukan evaluasi dengan cara melakukan penilaian menentukan atribut terpilih untuk dapat diterapkan pada final desain.

4. Tahap akhir adalah melakukan komunikasi final desain melalui hasil pemodelan desain untuk mendapatkan hasil prototipe.

\section{Landasan teori}

\section{Profil psikologi anak kecil (2-6 tahun)}

Terdapat hal yang perlu dipahami dari pengenalan tiga sisi perkembangan psikologi anak kecil. Ada 3 (tiga) sisi perkembangan masa usia dini yang berpengaruh pada psikologi anak, yaitu:

1. Tumbuh kembang fisik

Perkembangan fisik anak usia dini merupakan hasil dari interaksi antara faktor keturunan dan lingkungan. Pada masa ini, penting untuk menciptakan lingkungan yang dapat merangsang pertumbuhan dengan membiarkan anak bereksplorasi dan mencoba hal baru. Hal ini karena otak tumbuh pesat pada usia 2-6 tahun, hingga mencapai sekitar $90 \%$ otak dewasa, yang diiringi oleh pesatnya kemampuan kognitif (nalar/berpikir).

2. Tumbuh kembang kognitif

Perkembangan kognitif anak sudah mulai dapat dikenali ketika anak-anak sudah mampu belajar dengan menggunakan simbol-simbol, seiring perkembangan linguistik atau kemampuan mereka dalam menguasai bahasa yang digunakan. Pada masa ini, imajinasi dan memori juga Hanya saja, anak pada masa ini belum sepenuhnya mampu berpikir logis, hubungan sebab-akibat, persepsi waktu, dan perbandingan.

3. Tumbuh kembang sosial dan emosional

Perkembangan sosial dan emosional merupakan dua sisi yang saling berkaitan. Perkembangan ini biasanya melibatkan perolehan nilai, pengetahuan, dan keterampilan yang memungkinkan anak-anak untuk berhubungan dengan orang lain secara efektif dan berkontribusi dengan cara yang positif kepada keluarga, sekolah dan masyarakat.

Dapat disimpulkan bahwa didalam perancangan sebuah desain produk bagi anak umur 2-6 tahun perlu diperhatikan adalah produk tersebut tidak hanya dapat diaplikasikan namun layaknya dapat menambah nilai edukatif koqnitif dan emosional bagi anak kecil. Selain itu adalah perlu dipertimbangkan juga kesesuaian produk dengan jangkauan fisik anak kecil [8].

Kreativitas seseorang mulai meningkat pada usia 3 tahun dan mencapai puncaknya pada usia 4,5 tahun, dimana umumnya akan segera menurun apabila tidak diupayakan agar kemampuan tersebut tetap terus berkembang [9] dan [10].
Terkait dengan produk untuk anak-anak yang dirancang untuk kepentingan pendidikan bagi anak prasekolah maka lebih baik berlaku sebagai produk yang edukatif. Menurut peneliti tersebut produk tersebut dapat memiliki beberapa ciri sebagai berikut:

1. Mempunyai tingkat keamanan yang tinggi.

2. Dapat digunakan berulang-ulang dan tidak mudah rusak.

3. Dirancang untuk mengembangkan ketrampilan motorik dan kecerdasan anak.

4. Dapat disusun bermacam-macam bentuk sesuai keinginan anak.

5. Merangsang kreatifitas anak.

\section{Barang bawaan anak Taman Kanak-kanak (TK)}

Secara umum peralatan sekolah anak TK masih standar dikarenakan jam belajar tidak lama dan masih berkisar pada penerapan pengenalan dunia luar bagi anak-anak. Terdapat beberapa peralatan Sekolah Anak TK yang umum digunakan anak TK ketika bersekolah yakni: tas, tempat makan, tempat minum, baju seragam/ ganti, alat tulis, sepatu/sandal. Barang bawaan tersebut dapat dijadikan referensi dalam perancangan alat sterilisasi Covid dengan menentukan ukuran rata-rata produk tersebut untuk pertimbangan volume produk nantinya [11].

\section{Produk sterilisasi Covid-19 dengan sinar $U V$}

Produk sterilisasi pada beberapa penelitian menunjukan perkembangan mulai dengan sistem disinfektan sampai dengan penggunaan sinar x-ray untuk mendeteksi panas tubuh seseorang yang terinfeksi Covid. Menurut penelitian terkait perancangan prototip produk sterilisasi Covid dengan sinar UV menunjukan bahwa sinar $U V$ dapat membunuh virus dalam jarak jangkauan diameter area sekitar $50 \mathrm{~cm}$ dengan waktu sekitar 10 detik. Hal ini membuktikan bahwa produk sterilisasi ini efektif membunuh virus Covid dengan area yang luas dan dengan waktu sangat singkat serta dengan biaya terjangkau dibandingkan semprot disinfektan. Pada artikel tersebut menunjukan bahwa prototype produk dapat berupa sebuah kotak dengan didalamnya dipasang beberapa lampu sinar $U V$. Sinar $U V$ dapat dihasilkan dengan menggunakan lampu neon $U V[12]$.

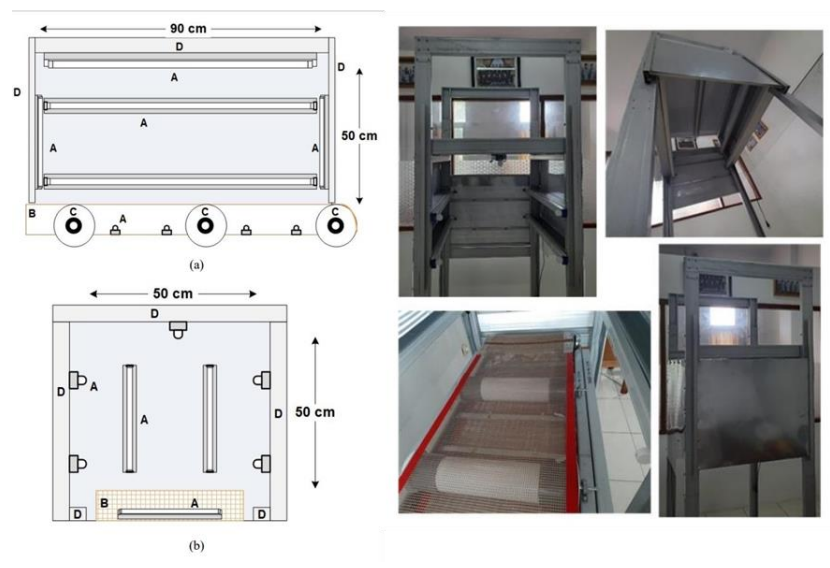

Gambar 2. Prototype produk eksisting alat sterilisasi Covid dengan menggunakan lampu UV.

Perlu diperhatikan adalah bahwa didalam menggunakan lampu sinar $U V$ untuk sterilisasi virus Covid harus dalam 
keadaaan ruang tertutup (Gambar 2 dan Tabel 1). Hal ini dikarenakan bahwa kulit manusia yang terpapar sinar $U V$ dalam waktu yang berkepanjangan akan mengakibatkan iritasi hingga kanker dan juga sinar neon $U V$ cukup mengganggu jika diamati terus menerus oleh mata.

Berdasarkan produk eksisting selanjutnya dilaksanakan pengembangan desain sehingga lebih sesuai untuk anakanak pra sekolah. Produk eksisting mempunyai kelebihan dalam aspek kemudahan dan kepraktisan serta jangkauan yang luas dan kecepatan membunuh virus yang baik. Sedangkan kekurangan adalah produk harus dalam kondisi tertutup jika digunakan karena sinar UV dapat mengganggu kulit dan matq jika terpapar terus menerus. Kemudian ukuran prototipe yang tergantung dari ukuran panjang dari lampu neon UV.

Tabel 1. Waktu sinar $U V$ membunuh virus Covid-19 dengan panjang paket jangkauan jarak.

\begin{tabular}{|c|r|}
\hline $\begin{array}{c}\text { Panjang Paket } \\
(\mathbf{c m})\end{array}$ & $\boldsymbol{E}_{\boldsymbol{t} \boldsymbol{9 0}}$ (detik) \\
\hline 70 & 15,91 \\
\hline 65 & 15,91 \\
\hline 60 & 12,43 \\
\hline 55 & 12,43 \\
\hline 50 & 10,29 \\
\hline 45 & 10,29 \\
\hline 40 & 9,05 \\
\hline 35 & 9,05 \\
\hline 30 & 7,42 \\
\hline 25 & 7,42 \\
\hline 20 & 7,84 \\
\hline 15 & 7,84 \\
\hline 10 & 7,39 \\
\hline 5 & 7,39 \\
\hline$<5$ & 7,37 \\
\hline
\end{tabular}

\section{HASIL DAN PEMBAHASAN}

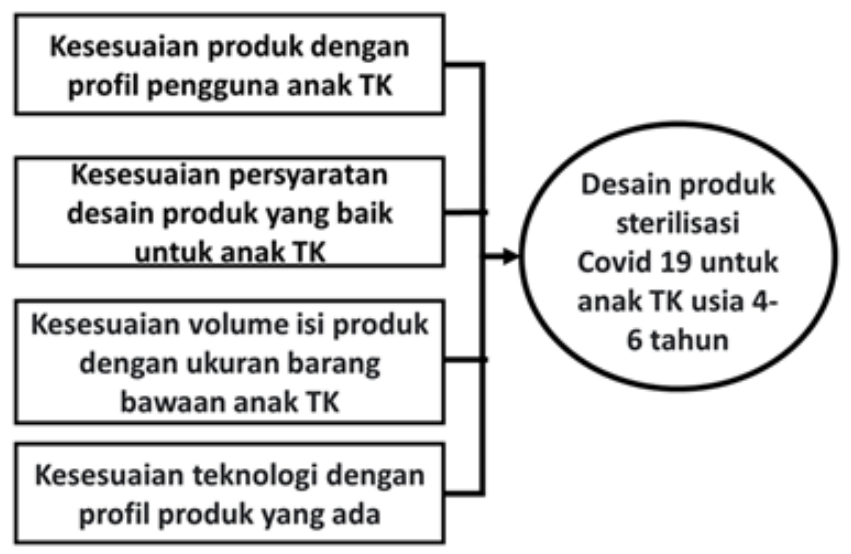

Gambar 3. Atribut tujuan kebutuhan desain.

Proses perancangan menggunakan metode analisis atribut fungsi yang tujuannya adalah untuk menetapkan desain dan fungsi-fungsi yang diperlukan untuk batas sistem percancangan produk yang baru. Metode analisis fungsi menggambarkan sistem input-output dalam proses pembuatan produk sterilisasi sinar UV dengan prinsip black box. Metode perancangan black box ini menawarkan pertimbangan fungsi esensial alat, dimana desain atau sistem yang dirancang harus memuaskan [13]. Prosedur black box adalah sebagai berikut:

1. Menyusun fungsi sistem secara keseluruhan produk dalam bentuk transformasi input/output.

2. Mengelompokkan sub-sub fungsi.

3. Menggambar blok diagram.

4. Menggambar pembatasan sistem.

5. Mencari komponen yang sesuai untuk mengahasilkan sub fungsi dan kesesuaian desain dengan sub-sub fungsi tersebut.

Tabel 2. Atribut tujuan kebutuhan desain dengan kriteria atribut.

\begin{tabular}{l|l}
\hline \hline \multicolumn{1}{c|}{ Tujuan } & \multicolumn{1}{c}{ Kriteria atribut } \\
\hline \hline $\begin{array}{l}\text { 1. Kesesuaian produk } \\
\text { dengan profil } \\
\text { pengguna anak TK. }\end{array}$ & $\begin{array}{l}\text { Produk dapat menambah nilai bagi anak } \\
\text { kecil: kognitif (1), emosional (2), dan } \\
\text { sesuai jangkauan anak-anak (3). }\end{array}$ \\
\hline $\begin{array}{l}\text { 2. Kesesuaian } \\
\text { persyaratan desain } \\
\text { produk yang baik } \\
\text { untuk anak TK. }\end{array}$ & $\begin{array}{l}\text { 1. Mempunyai tingkat keamanan yang } \\
\text { tinggi. }\end{array}$ \\
$\begin{array}{l}\text { 2. Dapat digunakan berulang-ulang dan } \\
\text { tidak mudah rusak. }\end{array}$ \\
$\begin{array}{l}\text { 3. Dirancang untuk mengembangkan. } \\
\text { ketrampilan motorik dan kecerdasan } \\
\text { anak. }\end{array}$ \\
$\begin{array}{l}\text { 4. mempunyai bentuk sesuai selera } \\
\text { anak. }\end{array}$ \\
$\begin{array}{l}\text { 5. Merangsang kreatifitas anak. } \\
\text { isi produk dengan } \\
\text { ukuran barang bawaan } \\
\text { anak TK }\end{array}$ & $\begin{array}{l}\text { Produk dapat memuat: sepatu/sandal (1), } \\
\text { baju seragam/ganti (2), tempat makan } \\
\text { (3), alat tulis (4), tas (5), dan tempat } \\
\text { minum (6). }\end{array}$ \\
\hline $\begin{array}{l}\text { 4. Kesesuaian } \\
\text { teknologi dengan } \\
\text { profil produk yang ada }\end{array}$ & $\begin{array}{l}\text { 1. Tertutup } \\
\text { 2. Menyesuaikan ukuran lampu neon }\end{array}$ \\
\hline
\end{tabular}

Setelah memahami prosedur black box dalam perancangan desain, maka peneliti mengimplementasikan atribut-atribut yang kebutuhan produk kedalam sub bagian sistem inputoutput dalam black box. Berdasarkan tinjauan dan referensi maka dapat diklasifikasikan kebutuhan untuk perancangan produk adalah sebagai berikut (Gambar 3):

Tabel 3. Penilaian kriteria atribut kesesuaian produk

\begin{tabular}{|c|c|c|c|}
\hline Premier & Tujuan & Kriteria atribut & $\begin{array}{l}\text { Tingkat } \\
\text { kepenti- } \\
\text { ngan }\end{array}$ \\
\hline \multirow{9}{*}{ Desain } & \multirow{3}{*}{ Kognitif } & Penggunaan mudah & 4 \\
\hline & & $\begin{array}{l}\text { Penggunaan } \\
\text { menambah keilmuan }\end{array}$ & 3 \\
\hline & & $\begin{array}{l}\text { Penggunaan } \\
\text { dikerjakan } \\
\text { berkelompok }\end{array}$ & 2 \\
\hline & \multirow[t]{3}{*}{ Emosional } & $\begin{array}{l}\text { Bentuk produk } \\
\text { menarik bagi anak- } \\
\text { anak }\end{array}$ & 4 \\
\hline & & $\begin{array}{l}\text { Produk dapat memicu } \\
\text { kesenangan anak-anak }\end{array}$ & 3 \\
\hline & & $\begin{array}{l}\text { Produk menggugah } \\
\text { imajinasi anak-anak }\end{array}$ & 3 \\
\hline & \multirow{3}{*}{$\begin{array}{l}\text { Sesuai } \\
\text { jangkauan } \\
\text { anak-anak }\end{array}$} & $\begin{array}{l}\text { Jarak antar tombol } \\
\text { mudah dijangkau }\end{array}$ & 3 \\
\hline & & $\begin{array}{l}\text { Ukuran produk sesuai } \\
\text { antropometri anak- } \\
\text { anak }\end{array}$ & 3 \\
\hline & & $\begin{array}{l}\text { Penggunaan produk } \\
\text { dapat dijangkau anak- } \\
\text { anak }\end{array}$ & 4 \\
\hline
\end{tabular}

1. Kesesuaian produk dengan pengguna (Anak TK).

Produk harusnya dapat menambah nilai edukatif untuk 
perkembangan nilai koqnitif, emosional dan sesuai dengan jangkauan anak kecil.

2. Kesesuaian syarat produk yang baik bagi anak TK.

Aman, tidak mudah rusak, dapat mengembangkan ketrampilan motorik dan kecerdasan anak, mempunyai bentuk sesuai dengan selera anak-anak dan dapat merangsang kreativitas anak.

3. Kesesuaian volume isi produk dengan ukuran barang bawaan anak TK.

Volume produk harusnya dapat memuat barang bawaan anak TK yang sering dibawa mulai dari sandal/ sepatu, tempat makan, tempat minum, baju seragam/ ganti, alat tulis, hingga tas ransel.

4. Kesesuaian teknologi dengan profil produk eksisting Pada tinjauan eksisting terkait produk eksisting sterilisasi Covid dengan sinar $U V$ memiliki penggunaan dalam bentuk tertutup dan dapat menggunakan lampu neon $U V$ sesuai ukurannya.

Tabel 4. Penilaian kriteria atribut kesesuaian produk dengan kesesuaian syarat desain produk yang baik bagi anak TK.

\begin{tabular}{|c|c|c|c|}
\hline Premier & Tujuan & Kriteria atribut & $\begin{array}{l}\text { Tingkat } \\
\text { kepenti- } \\
\text { ngan }\end{array}$ \\
\hline \multirow{15}{*}{ Desain } & \multirow{3}{*}{$\begin{array}{l}\text { Mempunyai } \\
\text { tingkat } \\
\text { keamanan yang } \\
\text { tinggi }\end{array}$} & $\begin{array}{l}\text { Bentuk Tidak } \\
\text { menyebabkan luka } \\
\text { (sudut tajam) }\end{array}$ & 3 \\
\hline & & $\begin{array}{l}\text { Lampu UV diletakkan } \\
\text { tertutup }\end{array}$ & 4 \\
\hline & & Produk tidak berbau & 2 \\
\hline & \multirow{3}{*}{$\begin{array}{l}\text { Dapat } \\
\text { digunakan } \\
\text { berulang-ulang } \\
\text { dan tidak } \\
\text { mudah rusak }\end{array}$} & $\begin{array}{l}\text { Material awet dan tahan } \\
\text { lama }\end{array}$ & 4 \\
\hline & & Material tahan benturan & 3 \\
\hline & & Material tahan panas & 3 \\
\hline & \multirow{3}{*}{$\begin{array}{l}\text { Dirancang } \\
\text { untuk } \\
\text { mengembangka } \\
\mathrm{n} \text { ketrampilan } \\
\text { motorik dan } \\
\text { kecerdasan } \\
\text { anak }\end{array}$} & $\begin{array}{c}\text { Terdapat proses } \\
\text { dalam pemakaian produk }\end{array}$ & 4 \\
\hline & & $\begin{array}{l}\text { Memperbanyak tombol } \\
\text { pemakaian }\end{array}$ & 1 \\
\hline & & $\begin{array}{l}\text { Memperbanyak } \\
\text { rangkaian buka tutup } \\
\text { produk }\end{array}$ & 2 \\
\hline & \multirow{3}{*}{$\begin{array}{l}\text { Mempunyai } \\
\text { bentuk sesuai } \\
\text { selera anak } \\
\end{array}$} & Bentuk kartun & 4 \\
\hline & & Bentuk binatang lucu & 3 \\
\hline & & Bentuk Bunga & 3 \\
\hline & \multirow{3}{*}{$\begin{array}{l}\text { Merangsang } \\
\text { kreatifitas anak }\end{array}$} & Warna yang menarik & 4 \\
\hline & & Grafis yang menarik & 3 \\
\hline & & Gambar yang menarik & 2 \\
\hline
\end{tabular}

Tabel 5. Penilaian kriteria atribut kesesuaian produk dengan kesesuaian volume isi produk dengan ukuran bawaan anak TK.

\begin{tabular}{|c|c|c|c|}
\hline \multirow{18}{*}{$\begin{array}{l}\text { Ukuran } \\
\text { dan } \\
\text { volume }\end{array}$} & \multirow{3}{*}{$\begin{array}{l}\text { sepatu/ } \\
\text { sandal }\end{array}$} & Ukuran $30: 18,5 \mathrm{~cm}$ & 2 \\
\hline & & Ukuran $32: 20 \mathrm{~cm}$ & 4 \\
\hline & & Ukuran $33: 21 \mathrm{~cm}$ & 3 \\
\hline & \multirow{3}{*}{$\begin{array}{l}\text { Baju } \\
\text { seragam/ } \\
\text { ganti }\end{array}$} & Ukuran $4: 32 \mathrm{~cm} \mathrm{x} 46 \mathrm{~cm}$ & 2 \\
\hline & & Ukuran $6: 36 \mathrm{~cm} \times 50 \mathrm{~cm}$ & 3 \\
\hline & & Ukuran $8: 40 \mathrm{~cm}$ x $54 \mathrm{~cm}$ & 4 \\
\hline & \multirow{3}{*}{$\begin{array}{l}\text { Tempat } \\
\text { makan }\end{array}$} & $19 \times 15 \times 6 \mathrm{~cm}$ & 2 \\
\hline & & $20 \times 16 \times 7 \mathrm{~cm}$ & 3 \\
\hline & & $22 \times 18 \times 8 \mathrm{~cm}$ & 4 \\
\hline & \multirow[t]{3}{*}{ Alat tulis } & P: $15 \mathrm{~cm} \mathrm{x} \mathrm{L:} 1-2 \mathrm{~cm} \times \mathrm{T}: 20 \mathrm{~cm}$ & 2 \\
\hline & & P: $18 \mathrm{~cm} \times$ L: $1-2 \mathrm{~cm} \times \mathrm{T}: 20 \mathrm{~cm}$ & 3 \\
\hline & & P: $20 \mathrm{~cm} \mathrm{x} \mathrm{L:} 1-2 \mathrm{~cm} \times \mathrm{T}: 24 \mathrm{~cm}$ & 4 \\
\hline & \multirow[t]{3}{*}{ Tas } & 11 inchi $\times 6$ inchi & 2 \\
\hline & & 15 inchi $\times 8$ inchi & 3 \\
\hline & & 19 inchi $x 9$ inchi & 4 \\
\hline & \multirow{3}{*}{$\begin{array}{l}\text { Tempat } \\
\text { minum }\end{array}$} & Diameter $7 \mathrm{~cm}$, Tinggi $22 \mathrm{~cm}$ & 2 \\
\hline & & Diameter $8 \mathrm{~cm}$, Tinggi $24 \mathrm{~cm}$ & 3 \\
\hline & & Diameter $8 \mathrm{~cm}$, Tinggi $28 \mathrm{~cm}$ & 4 \\
\hline
\end{tabular}

Tabel 6. Penilaian kriteria atribut kesesuaian produk dengan volume isi komponen produk.

\begin{tabular}{|c|c|c|c|}
\hline \multirow{6}{*}{$\begin{array}{l}\text { Ukuran } \\
\text { dan } \\
\text { Desain }\end{array}$} & \multirow{3}{*}{ Neon UV } & $\begin{array}{l}\text { Uk kecil: } 325 \mathrm{~mm} \times 21 \mathrm{~mm} \times \\
32.3 \mathrm{~mm}\end{array}$ & 3 \\
\hline & & $\begin{array}{l}\text { Uk sedang: } 885 \mathrm{~mm} \times 21 \mathrm{~mm} \times \\
32.3 \mathrm{~mm}\end{array}$ & 4 \\
\hline & & $\begin{array}{l}\text { Uk besar: } 1185 \mathrm{~mm} \times 21 \mathrm{~mm} \mathrm{x} \\
32.3 \mathrm{~mm}\end{array}$ & 3 \\
\hline & \multirow[t]{3}{*}{ Tertutup } & Pintu Buka-tutup atas & 3 \\
\hline & & Pintu Buka-tutup samping & 4 \\
\hline & & Pintu Buka-tutup memutar & 2 \\
\hline
\end{tabular}

\begin{tabular}{|c|c|c|}
\hline Premier & Tujuan & Kriteria atribut \\
\hline \multirow{3}{*}{$\begin{array}{l}\text { Kesesuaian } \\
\text { produk dengan } \\
\text { profil pengguna } \\
\text { anak TK }\end{array}$} & Kognitif & Penggunaan mudah \\
\hline & Emosional & $\begin{array}{l}\text { Bentuk produk menarik } \\
\text { bagi anak-anak }\end{array}$ \\
\hline & $\begin{array}{l}\text { Sesuai jangkauan } \\
\text { anak-anak }\end{array}$ & $\begin{array}{l}\text { Penggunaan produk } \\
\text { dapat dijangkau anak- } \\
\text { anak }\end{array}$ \\
\hline \multirow{3}{*}{$\begin{array}{l}\text { Produk dapat } \\
\text { menambah nilai } \\
\text { bagi anak kecil }\end{array}$} & $\begin{array}{l}\text { Mempunyai tingkat } \\
\text { keamanan yang tinggi }\end{array}$ & $\begin{array}{l}\text { Lampu UV diletakkan } \\
\text { tertutup }\end{array}$ \\
\hline & $\begin{array}{l}\text { Dapat digunakan } \\
\text { berulang-ulang dan } \\
\text { tidak mudah rusak }\end{array}$ & $\begin{array}{l}\text { Material awet dan tahan } \\
\text { lama }\end{array}$ \\
\hline & $\begin{array}{l}\text { Dirancang untuk } \\
\text { mengembangkan } \\
\text { ketrampilan motorik } \\
\text { dan kecerdasan anak }\end{array}$ & $\begin{array}{l}\text { Terdapat proses dalam } \\
\text { pemakaian produk }\end{array}$ \\
\hline \multirow{2}{*}{$\begin{array}{l}\text { Kesesuaian } \\
\text { persyaratan } \\
\text { desain produk } \\
\text { yang baik untuk } \\
\text { anak TK }\end{array}$} & $\begin{array}{l}\text { Mempunyai bentuk } \\
\text { sesuai selera anak }\end{array}$ & Bentuk kartun lucu \\
\hline & $\begin{array}{l}\text { Merangsang kreatifitas } \\
\text { anak }\end{array}$ & Warna yang menarik \\
\hline \multirow{6}{*}{$\begin{array}{l}\text { Kesesuaian } \\
\text { volume isi } \\
\text { produk dengan } \\
\text { ukuran barang } \\
\text { bawaan anak } \\
\text { TK }\end{array}$} & sepatu/ sandal & Ukuran $32: 20 \mathrm{~cm}$ \\
\hline & Baju seragam/ ganti & $\begin{array}{l}\text { Ukuran } 8: 40 \mathrm{~cm} \mathrm{x} 54 \\
\mathrm{~cm}\end{array}$ \\
\hline & tempat makan & $22 \times 18 \times 8 \mathrm{~cm}$ \\
\hline & alat tulis & $\begin{array}{l}\text { P: } 20 \mathrm{~cm} \times \text { L: } 1-2 \mathrm{~cm} \mathrm{x} \\
\text { T: } 24 \mathrm{~cm}\end{array}$ \\
\hline & tas & 19 inchi $x 9$ inchi \\
\hline & tempat minum & $\begin{array}{l}\text { Diameter } 8 \mathrm{~cm}, \quad \text { Tinggi } \\
28 \mathrm{~cm}\end{array}$ \\
\hline
\end{tabular}

Setelah atribut kebutuhan didapatkan, selanjutnya tim peneliti dapat menjabarkan detail masing-masing atribut kedalam proses black-box, seperti dapat dilihat pada Tabel 2.

Setelah tujuan atribut diperoleh selanjutnya dibuat daftar untuk pemilihan alternatif kriteria dari atribut, penilaian menggunakan skala 1-5, dengan tahapan $1=$ kurang hingga 5 = sangat dibutuhkan, Selanjutnya dapat dilihat pada Tabeltabel 3, 4, 5, 6, dan 7. Hasil desain dapat dilihat pada Gambar-gambar 4 dan 5

\section{Pemodelan desain produk}

Selanjutnya tim peneliti melakukan pemodelan dengan menerapkan pilihan atribut yang terpilih kedalam pemodelan desain produk. Peneliti menggunakan beberapa tahapan didalam melakukan pemodelan produk, sebagai berikut:

1. Sketsa Desain: dimana peneliti membuat dasar pemodelan dengan proses manual, alat yang digunakan adalah dengan alat gambar manual dan bebrapa lembar kertas.

2. Pemodelan Digital 2D: disini peneliti melanjutkan hasil sketsa menjadi sebuah bentuk gambar kerja / gambar teknik dimana gambar berupa gambar tampak produk disertai ukuran dan dimensi yang sesuai dengan hasil 
final desain. Peneliti menggunakan program Autocad untuk melakukan pemodelan digitalisasi 2D.

3. Pemodelan Digital 3D: Tahapan terakhir adalah peneliti melakukan pemodelan dalam bentuk 3D dimana mempunyai kedalam bentuk dan volume serta wujud seperti prototype sehingga diharapkan hasil akhir produksi nantinya bentuk desain tidak jauh berbeda. Pemodelan dilakukan dengan menggunakan lanjutan gambar digital 2D sebagai dasar dan disempurnakan menjadi wujud 3D. Program yang digunakan peneliti adalah 3DSmax.

\section{Desain final}

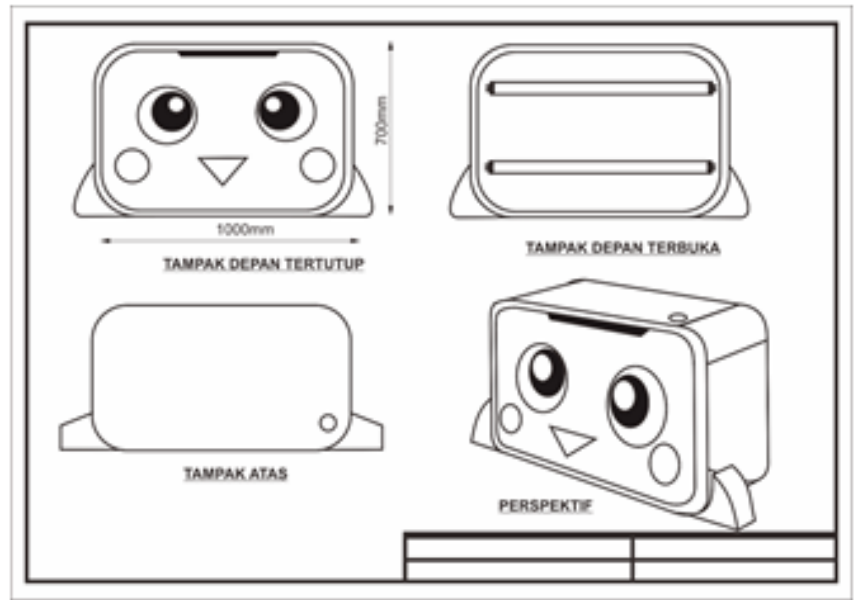

Gambar 4. Gambar Kerja Digital 2D
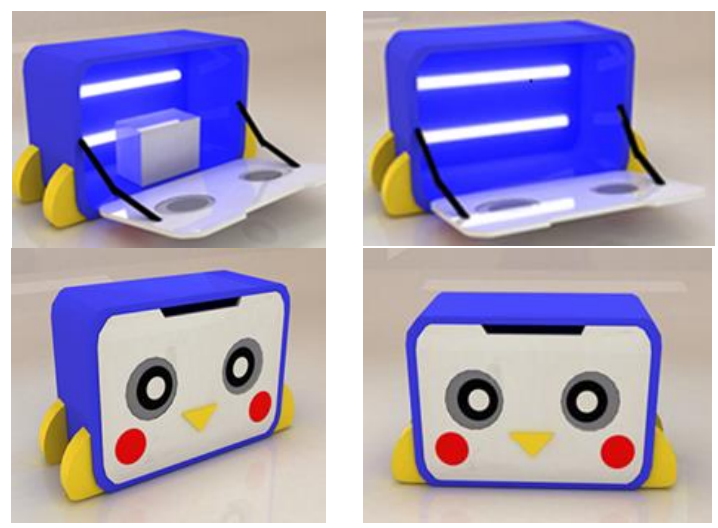

Gambar 5. Desain final 3D Produk pada kondisi terbuka dan tertutup.

\section{KESIMPULAN DAN SARAN}

Desain sterilisasi alat Covid-19 ini adalah hasil implementasi dari sinergi antara peran desainer sebagai pengelola input data dari responden menjadi bentuk visual. Pada desain terebut dapat menunjukan bagaimana peran unsur dari perancangan dalam membentuk karakter desain sebagai berikut:

1. Fungsional: dalam aspek fungsional, desainer tidak merubah fungsi utama produk eksisting yakni sebagai produk steriliasi Covid engan sinar UV, namun desainer menambahkan beberapa point tambahan lain didalam desain yakni Produk yang dapat lebih ramah bagi anak dengan desain yang menarik dan tertutup serta menyesuaikan dengan besaran barang bawaan anak TK/Playgroup

2. Estetika: Desainer memberikan unsur estetika pada bentuk produk yang lucu mengikuti bentuk kartun binatang agar terlihat menarik dan unik, namun tidak merubah fungsi utama dari produk

3. Makna dari desain: warna biru dan putih pada desain ingin mengesankan produk mengikuti bentuk kartun pinguin yang lucu.

Penelitian ini bertujuan utama adalah untuk mendapat desain yang diinginkan dari selera anak kecil melalui tahapan penelitian selain itu desain itu mencoba membantu kinerja dari desainer yang bersifat visual dan kreatif melalui hasil pengolahan data dari olah data yang bersifat deduktif. Dalam penelitian ini menunjukan hasil dari dapat diolah desainer menjadi bentuk visual dan new product development, peran dari metode black box juga dapat mempermudah arah desainer dalam menemukan karakter visual yang diperlukan dan desain menggunakan proses teknologi juga dapat mempercepat proses kerja desainer.

Penelitian ini memiliki keterbatasan waktu yakni pengukuran kembali hasil desain yang sudah diolah desainer di nilai kembali kepada responden berikutnya, apakah hasil desain yang baru tersebut dapat meningkatkan ekspektasi atau kepuasan pengunjung dari produk sebelumnya dan juga penelitian ini juga terbatas pada ruang lingkup anak kecil dimana kebutuhan responden yang juga belum terukur secara eksakta.

Saran dalam penelitian selanjutnya adalah bagaimana peneliti selanjutnya dapat lebih mudah memberikan pemahaman kepada desain melalui penelitian dengan mengisi kuisioner serta menggunakan berbagai metode yang lebih terkini untuk memandu desainer agar dapat bergerak menentukan arah desainnnya.

\section{UCAPAN TERIMA KASIH}

Penulis mengucapkan terima kasih kepada Universitas Dinamika terutama pada bagian PPM (Pusat Penelitian dan Pengabdian Masyarakat) yang telah banyak membantu dan membimbing terhadap proses penulisan dan tahapan penelitian. Terima kasih juga kepada tim riset dan pihak Mahasiswa S1 Desain Produk yang ikut dalam penyelesain penelitianini.

\section{DAFTAR PUSTAKA}

[1] Susanna, When will the COVID-19 Pandemic in Indonesia End? Jurnal Kesehatan Masyarakat Nasional (National Public Health Journal). 2020; 15 (4): 160-162. (2020),

[2] Aulia. Covid-19 Prevention Education With The Health Protocol of $5 \mathrm{M}$ and The Importance Of Multivitamins During Covid-19 Pandemic. Jurnal Abdi Masyarakat Vol. 2, No.1 Mei 2021, Hal. 133139.(2021)

[3] Kampf, Todt dan Pfaender (2020), Persistence of coronaviruses on inanimate surfaces and their inactivation with biocidal agents. Persistence of coronaviruses on inanimate surfaces and their inactivation with biocidal agents 104 (2020) 246-251.

[4] Gerchman, Mamane dan dan Friedman. UV-LED disinfection of Coronavirus: Wavelength effect. Journal of Photochemistry and Photobiology B: Biology. Volume 212, November 2020, 112044. 
Yosef Richo, Martinus Sony, dan Hafidz Sirojul

Desain Alat Sterilisasi Covid-19 dengan Teknologi Sinar UV yang Ramah untuk Anak-anak Usia 2-6 Tahun

[5] Punaji. Metode Penelitian Pendidikan \& Pengembangan. Penerbit Prenadamedia Group- Jakarta (2015)

[6] Achmadi, Abu dan Narbuko, Cholid. Metodologi Penelitian. (Bumi Aksara. Jakarta. 2015)

[7] Ginting. "Perancangan Produk", Graha Ilmu Jakarta. (2009).

[8] Masganti. Psikologi Perkembangan Anak Usia Dini Jilid I. Penerbit: Perdana Publishing Medan - ISBN 978-602-6970-00-8. (2015).

[9] Aini Loita Early Childhood: Jurnal Pendidikan Karakteristik Pola Gambar Anak Usia Dini E-ISSN : 2579-7190 | Vol.1 No. 1, (2017).

[10] Rahmawati, Bustari, Dan Isbianti, "Pengadaan Dan Penggunaan Sarana Pendidikan di Taman Kanak-Kanak Negeri di Propinsi Daerah Istimewa Yogyakarta”. Jurnal Penel Pengad Fasilitas (2016).
[11] Watini, Implementasi Model Pembelajaran Sentra pada TK Labschool STAI Bani Saleh Bekasi. Jurnal Obsesi: Jurnal Pendidikan Anak Usia Dini. Volume 4 Issue 1, Pages 110-123. ISSN: 2549-8959 (Online) 2356-1327 (Print). (2020).

[12] Reza Satria Rinaldi, Ika Novia Anggraini, (Design of Package Sterilization UV-C Disinfectant Systems to Prevent the Spread of Covid-19) -Jurnal Nasional Teknik Elektro dan Teknologi Informasi | Vol. 10, No. 1, Februari (2021).

[13] Ginting, Batubara dan Widodo. Desain Ulang Produk Tempat Tissue Multifungsi Dengan Menggunakan Metode Quality Function Deployment. Jurnal Sistem Teknik Industri, Vol. 19 No. 2, Juli 2017 